УДК 620.22:072.34

Л.А. ЧУРСІНА, Г.Г. ГЛУХОВА, Н.В. НЕЖЛУКЧЕНКО

Херсонський начіональний технічний університет

\title{
ТЕНДЕНЦІЇ РОЗВИТКУ ВІТЧИЗНЯНОГО РИНКУ ТРИКОТАЖНИХ ВИРОБІВ
}

\author{
Л.А. ЧУРСИНА, А.Г. ГЛУХОВА, Н.В. НЕЖЛУКЧЕНКО \\ Херсонский национальный технический университет
}

\section{ТЕНДЕНЦИИ РАЗВИТИЯ ОТЕЧЕСТВЕННОГО РЫНКА ТРИКОТАЖНЫХ ИЗДЕЛИЙ}

\section{CHURSINA, H. HLUKHOVA, N. NEGLUKCHENKO}

Kherson national technical university

\section{DEVELOPMENT TRENDS OF THE DOMESTIC KNITWEAR MARKET}

\begin{abstract}
Мета. Визначення основних причин кризового стану вітчизняної галузі трикотажного виробництва та постановка основних завдань, які необхідно розв'язати для відродження та сталого розвитку вітчизняного ринку трикотажних виробів.

Методика. Для досліджень, результати яких наведені у даній статті, було використано соиіологічні методи досліджень.

Результати. Встановлено, щзо вітчизняна трикотажсна продукція займає досить малу частку на українському ринку, необхідно розширювати асортимент продукиії, створюючи конкуренщію імпортній продукиії сумнівної якості. 3 иією метою необхідно створити власну сировинну базу для трикотажної промисловості за рахунок відродження вітчизняного льоно- та коноплепереробного комплексу; оновити технічну базу, що дало б змогу збільшити виробничі потужності та підвищити якість продукиї до європейських стандартів. Основними тенденціями у розвитку ринку трикотажсних товарів в Україні є: скорочення внутрішнього попиту на трикотажні товари вітчизняного виробництва, щцо обумовлюється низькими цінами імпорту; переважання частки імпортованої продукції, щзо складає $76 \%$ від загального обсягу ринку трикотажних товарів (Китай, Білорусь, Туреччина); занепад вітчизняної сировинної бази. Вітчизняні трикотажні вироби програють конкуренцію імпортним за критеріями: ціна-якість, відповідність тенденціям моди, повнота асортименту. Великі обсяги контрабанди товарів та демпінгові ціни іноземних конкурентів унеможливлюють успішну конкуренцію з боку вітчизняних товаровиробників; в Україні відсутня державна політика щзодо захисту інтересів вітчизняних виробників трикотажних виробів. За відповідних умов актуалізуються завдання пошуку шляхів ефективного регулювання ринку трикотажних виробів в Україні з урахуванням необхідності захисту та стимулювання розвитку вітчизняних виробників на організачійному рівні державної політики.

Необхідною умовою конкурентоспроможності вітчизняних трикотажних виробів як на внутрішньому, так $і$ на зовнішньому ринках, є залучення молодих дизайнерів у сферу виробництва білизняних виробів, які б могли розробити сучасну, модну продукцію. Необхідно залучати покупџів до формування не лише торгового, а ц̆ виробничого асортименту шляхом опитування продавиями або анкетування.
\end{abstract}


Наукова новизна. Встановлено, щ⿻о пріоритетними напрямками формування внутрішнього ринку трикотажних виробів є захист ринку від контрафактної продукиії; дотримання контролю за якістю $i$ иіною імпортованих товарів через прочедури сертифікачіï та ідентифікачіï й запровадження електронного декларування імпорту; застосування антидемпінгових заходів для захисту внутрішнього ринку від експансії закордонних виробників; зменшення обсягів тіньового обороту.

Практична значимість. Аналіз тенденцій розвитку ринку трикотажних виробів в Україні дав змогу визначити необхідні критерії відродження вітчизняного трикотажного виробництва.

Ключові слова: трикотажне виробництво, сертифікація, ідентифікаџія, тіньовий оборот, иүіна , якість.

\section{Постановка проблеми у загальному вигляді та іiї зв'язок із} важливими науковими чи практичними завданнями. Ринок трикотажних виробів $є$ складовим елементом системи забезпечення потреб населення країни у зручному, екологічному, естетичному та недорогому одязі. Нажаль, вітчизняна трикотажна промисловість на даний час не витримує світової конкуренції. Український ринок перевантажений не завжди якісною імпортною сировиною, переважання частки імпортованої продукції складає $76 \%$ від загального обсягу ринку трикотажних товарів (Китай, Білорусь, Туреччина). Поряд 3 тим, вітчизняні трикотажні вироби не користуються великим попитом серед населення. Частка вітчизняної трикотажної продукції на внутрішньому ринку становить лише 4 \%. При тому, що іï зменшення за п’ять років склало $6,4 \%$.

Відповідна динаміка свідчить про неспроможність вітчизняних підприємств витримати конкуренцію з іноземними виробниками трикотажної продукції (табл.1).

Таблиця 1

Частка продажу трикотажних виробів, що вироблені на території України

\begin{tabular}{|c|c|c|c|c|c|}
\hline \multirow{2}{*}{ Товарна група } & \multicolumn{5}{|c|}{ Роки } \\
\cline { 2 - 6 } & 2014 & 2015 & 2016 & 2017 & 2018 \\
\hline Трикотаж верхній та білизняний & 9,3 & 5,0 & 4,0 & 5,3 & 6,7 \\
\hline
\end{tabular}

За офіційною статистикою більше 45 \% внутрішнього ринку трикотажних виробів становлять товари, що були вироблені у Китаї. Найбільше було імпортовано колготок, панчох, шкарпеток, гольфів, светрів і пуловерів, тенісок і майок. За відповідних умов актуалізуються завдання пошуку шляхів ефективного регулювання ринку трикотажних виробів в Україні 3 урахуванням необхідності захисту та стимулювання розвитку вітчизняних виробників на організаційному рівні державної політики [1]. 
Аналіз попередніх досліджень. Проблематика з визначення тенденцій розвитку ринку трикотажних виробів детально викладена у дослідженнях вітчизняних і закордонних вчених О.С. Бавико [1], Н.Л. Супрун [2, 3], І.С. Галика, Б.Д. Семака [4], І.А. Іванченко [5], Ю.В. Нефьодова [6]. В межах комплексних досліджень економічного розвитку легкої промисловості визначені тенденції ринку трикотажного виробництва у публікаціях А.П. Гречан [7], Л.В. Дейнеко [8].

Цілі статті. Основним завданням, яке необхідно розв'язати для відродження розвитку вітчизняного ринку трикотажних виробів, $\epsilon$ встановлення причин, які зумовили кризовий стан даної галузі та визначення можливих шляхів їх усунення.

Об'єктами дослідження є: світовий та вітчизняний ринок трикотажних товарів.

Виклад основного матеріалу дослідження 3 повним обгрунтуванням отриманих наукових результатів. Для розв'язання основного завдання даної роботи з відродження розвитку ринку трикотажних виробів проаналізуємо стан експорту-імпорту трикотажних виробів в Україні.

У звязку з тим, що США та СС в межах здійснення політики захисту внутрішніх виробників обмежують доступ товарів, вироблених у КНДР на свої ринки, Китай буде намагатись компенсувати негативні впливи збільшенням своєї присутності на ринках інших країн, i, в першу чергу, країн пострадянського простору, де ці галузі перебувають у хронічній кризі $[2,3,9]$.

Одночасно необхідно зазначити наявність експортної складової у діяльності підприємств трикотажного сегменту легкої промисловості України. Працюючи за давальницькою сировиною, підприємства України у 2017 р. поставили на експорт трикотажної продукції на 402 млн. дол. США. Обсяг імпорту склав 264,1 млн. дол. США [2].

Найбільша кількість швейних виробів (в грошовому вираженні) поставляється до Данії (23\%), оскільки саме 3 цією країною укладено найбільше договорів, що регламентують роботу за давальницькою схемою. Близько $17 \%$ виробів поставлялось до Німеччини, $13 \%$ - Литви, $12 \%$ Угорщини, 8 \% - Росії, 7 \% - Італії, по 6 \% до Польщі і Франції [7-9].

У структурі експорту найбільша частка належить теніскам, майкам та іншій натільній білизні; светрам і пуловерам; костюмам і спідницям; сорочкам і жіночим блузкам.

Виробництво трикотажу в Україні представлено такими видами одягу як білизняний трикотаж (майки, труси, футболки, теніски 24 млн. шт.), верхній трикотаж (светри, кофти, пуловери, близько 10 млн. шт.). Також виробництво 
направлено на випуск панчішно-шкарпеткових виробів, спортивного одягу та одягу для дітей.

Але, через загальну непрозорість ринку, нерегульованість імпорту, обсяги якого щорічно збільшуються та нерівні умови конкуренції, обсяг імпорту трикотажних виробів постійно збільшується, що спричиняє негативний влив на господарську діяльність вітчизняних виробників трикотажних товарів.

Скрутне становище вітчизняних виробників трикотажу пояснюється перш за все загальноекономічною кризою в Україні, що спричинена клановоолігархічною моделлю економіки, за якої відбувається монополізація всіх іiі галузей. А також великим ступенем корупції, перш за все на митниці, технологічною відсталістю та відсутністю необхідних для модернізації фінансових ресурсів, залежністю від імпортованої сировини.

За період 2014-2018 рр. обсяги виробництва трикотажних виробів знизились на $20 \%$. У загальній структурі виробництва простежується: спад виробництва верхнього трикотажного одягу, приріст виробництва білизняного трикотажу та панчішно-шкарпеткових виробів. В торговій мережі переважають товари імпортного походження, що ставить економіку країни та споживачів у критичну залежність від кон'юнктури зовнішнього ринку.

За результатами соціологічного дослідження, проведеного фахівцями асоціації «Укрлегпром», ступеню задоволення українських споживачів якістю трикотажних виробів вітчизняного виробництва було встановлено, що основними причинами невеликих обсягів користування вітчизняними трикотажними товарами є: по-перше, низький рівень якості трикотажних виробів вітчизняного виробництва (27 \% покупців), невідповідність критерію ціна-якість (45\% респондентів); по-третє, мала кількість місць продажу вітчизняної продукції; по-четверте (33\% респондентів), малий асортимент (31\% респондентів); невідповідність сучасним тенденціям моди (14\% респондентів). Одночасно прослідковується загальна тенденція до збільшення частки покупок у спеціалізованих магазинах і супермаркетах. В контексті визначення проблемних питань 3 попиту на трикотажні вироби, можна зазначити, що покупця більше цікавить не країна виробника а якість, доступність та відповідність товару його функціональному призначенню.

Однією з головних особливостей у виробництв трикотажної білизни в Україні є невеликий розмір переважної більшості підприємств. Приблизно $65 \%$ продукції виготовляється на малих підприємствах 3 чисельністю робітників до 50 осіб. Невеликі розміри підприємств спрощують процеси 
організації та управління їх виробничою діяльністю, але обмеженість фінансових та матеріальних ресурсів не дозволяє таким підприємствам забезпечувати повномасштабний контроль показників якості продукції та іiі інноваційність.

Українським виробникам білизняного трикотажу необхідно звернути особливу увагу на високий рівень невідповідності існуючим нормам гігієнічних показників, що характеризують безпечність товарів. Найгіршими $€$ значення показника «Вміст хімічних волокон». Виробники допускають перевищення максимальних обмежень наявності волокон віскози у трикотажних виробах. Наявність у трикотажних виробах синтетичних волокон обумовлює доволі низькі показники відповідності нормам вмісту вільного формальдегіду та величини $\mathrm{pH}$. Перевищення допустимих норм не $\epsilon$ критичними для здоров'я людини, вони складають 5 - 20 \%. Це пояснюється відчутним послабленням контролюючого впливу спеціалізованих державних органів, повноваження яких у сфері технічного регулювання та захисту прав споживачів у процесі дерегуляції були відчутно обмежені. Виключення дитячого білизняного трикотажу 3 «Переліку продукції, що підлягає обов'язковій сертифікацій в Україні» пояснює застій у ситуації 3 відповідністю гігієнічних показників намаганням підприємців зберегти конкурентний рівень собівартості своєї продукції, використовуючи найдешевші матеріали та не витрачаючись на перевірку відповідності. В свою чергу це пов'язано із занепадом вітчизняної сировинної бази - більшість трикотажного полотна завозиться із за кордону, а те, що випускається на вітчизняних підприємствах, виготовлено з дорогої імпортної сировини. Це відбувається внаслідок повного занепаду вітчизняної льоно- та коноплепереробної галузі в Україні.

Зважаючи на те, що вітчизняна трикотажна продукція займає досить малу частку на українському ринку, необхідно розширювати асортимент продукції, створюючи конкуренцію імпортній продукції сумнівної якості. 3 цією метою необхідно придбати європейське сучасне обладнання, що дало б змогу збільшити виробничі потужності та підвищити якість продукції до європейських стандартів. Створити власну сировинну базу для трикотажної промисловості за рахунок відродження вітчизняного льоно- та коноплепереробного комплексу.

За відповідних умов актуалізуються завдання пошуку шляхів ефективного регулювання ринку трикотажних виробів в Україні 3 урахуванням необхідності захисту та стимулювання розвитку вітчизняних виробників на організаційному рівні державної політики. 
Висновки. Встановлено, що пріоритетними шляхами розвитку внутрішнього ринку трикотажних виробів в Україні є:

- захист ринку від контрафактної продукції;

- дотримання контролю за якістю і ціною імпортованих товарів через процедури сертифікації та ідентифікації й запровадження електронного декларування імпорту;

- застосування антидемпінгових заходів для захисту внутрішнього ринку від експансії закордонних виробників; зменшення обсягів тіньового обороту.

Визначено, що необхідною умовою конкурентоспроможності вітчизняних трикотажних виробів як на внутрішньому так і на зовнішньому ринках $€$ залучення молодих дизайнерів у сферу виробництва білизняних виробів, які б могли розробити сучасну, модну продукцію. Формування асортименту товарів таким чином, щоб у наявності завжди були товари, передбачені асортиментним переліком. Необхідно залучати покупців до формування не лише торгового, а й виробничого асортименту шляхом опитування продавцями споживачів або їх анкетування.

\section{Список використаних джерел}

1. Тенденції розвитку ринку трикотажних виробів в Україні [Електронний ресурс]/ Бавико O.Є. // Режим доступу: http: // www. economy.nayka.com.ua/?op=1\&z=5230.

2. Супрун Н. П. Аналітичний огляд асортименту та комплексна оцінка якості трикотажних полотен / Н.П. Супрун, Н.І. Осипенко, Ю.І. Островецька // Товарознавство та інновації. - 2012. - Вип. 4. - С. 116-124.

3. Механічна технологія текстильних матеріалів. Частина II. (Ткацьке, трикотажне та нетикане виробництва) : підручник / А.М. Слізков, В.Ю. Щербань, О.П. Кизимчук. - К.: КНУТД, 2018. - $276 \mathrm{c}$.

4. Галик І.С. Товарознавство трикотажних виробів: підручник для студентів товарознавчих спеціальностей вищих навчальних закладів / І.С. Галик, Б.Д. Семак. - Львів : «Магнолія 2006», $2011-221$ с.

5. Іванченко І.А. Сучасні особливості розвитку світового ринку одягу / І.А. Іванченко // Науковий вісник Полтавського університету економіки і торгівлі. - № 2 (53). - 2012. - С. $42-47$.

6. Нефьодова Ю.В. Напрямки розвитку легкої промисловості України Ю.В. Нефьодова // Вісник ДонНУЕТ. Серія: Економічні науки. - 2010. - № 3. - С. 20-24.

7. Гречан А.П. Теоретико-методологічні основи розвитку підприємств легкої промисловості на інноваційних засадах / А.П. Гречан. - К. : КНУТД, 2005. - 208 с.

8. Дейнеко Л.В. Розвиток внутрішнього ринку легкої промисловості: проблеми та можливості // Л.В. Дейнеко, М. Ю. Завгородня // Український соціум. - 2012. - № 1. - С. 83-98.

9. Товарна структура роздрібного товарообороту підприємств в Україні // Офіційний сайт Державної служби статистики України. [Електронний ресурс]. - Режим доступу: http://www.ukrstat.gov.ua.

10. Частка продажу споживчих товарів, які вироблені на території України, через 
торгову мережу підприємств // Офіційний сайт Державної служби статистики України. [Електронний ресурс]. - Режим доступу: http://www.ukrstat.gov.ua.

11. Проблеми вітчизняної промисловості [ Електронний ресурс]/ Марчук М. М., Щербак. Режим доступу: http://www.smida.gov.

Цель. Определение основных причин кризисного состояния отечественной отрасли трикотажного производства и постановка основных задач, которые необходимо решить для возрождения и стабильного развития отечественного рынка трикотажных изделий.

Методика. Для исследований, результаты которых приведены в данной статье, были применены сочииологические методы и проведен их анализ.

Результаты. Определено, что отечественная трикотажная продукция занимает достаточно малую долю на украинском рынке, необходимо расширять ассортимент продукиии, создавая конкуренциию импортной продукциии сомнительного качества. С этой целью необходимо приобрести европейское современное оборудование, что дало бы возможность увеличить производственные мощности и повысить качество продукиии до уровня европейских стандартов. Создать собственную сырьевую базу для трикотажной промышленности за счет возрождения отечественного льно- та коноплеперерабатывающего комплекса. Основныли тенденциями развития рынка трикотажных изделий в Украине являются: сокращение внутреннего спроса на трикотажные товары отечественного производства, что обусловлено низкими иенами импорта; большая часть импортной продукции, которая составляет 76 \% от общего объема ринка трикотажных товаров (Китай, Беларусь, Туриия); упадок отечественной сырьевой базы - большинство трикотажных полотен ввозится в страну; трикотажные изделия отечественных производителей проигрывают конкуренцию импортным по критериям: иена-качество, соответствию тенденциям моды, полноте ассортимента; устаревшая техническая база и отсутствие финансовых возможностей у отечественных предприятий мешают им быстро обновлять ассортимент трикотажных товаров; большие объемы контрабанды товаров и демпинговые цены иностранных конкурентов делают невозможным успешно конкурировать отечественным товаропроизводителям; в Украине отсутствуют государственная политика по защите интересов отечественных производителей трикотажных изделий. В соответствии с этим актуализируется задание поиска путей эффрективного регулирования рынка трикотажных изделий в Украине с учетом необходимости защиты и стимулирования развития отечественных производителей на организационном уровне государственной политики.

Необходимым условием конкурентоспособности отечественных трикотажных изделий как на внутреннем так и на внешнем рынках является привлечение молодых дизайнеров в сфере производства бельевых изделий, которые бы могли разработать современную, модную продукцию. Необходимо формировать ассортимент товаров таким образом, чтобы в наличии всегда были товары, предусмотренные ассортиментным списком. Необходимо привлекать покупателей к формированию не только торгового, а и производственного ассортимента путем опроса продавцами или анкетированием.

Научная новизна. Определено, что приоритетными направлениями формирования внутреннего рынка трикотажных изделий является защита рынка от контрафактной продукиии; контроль за качеством и иеной импортируемых товаров благодаря прочедуре сертификачии и идентификации, а также внедрение электронного декларирования импорта; применение антидемпинговых мероприятий для защиты внутреннего рынка от экспансии зарубежных производителей; уменьшение объёмов теневого оборота.

Практическое значение. Анализ тенденций развития ринка трикотажных изделий в Украине дает возможность определить необходимые критерии возрождения 
отечественного трикотажного производства.

Ключевые слова. Трикотажное производство, сертификация, идентификация, теневой оборот, цена, качество.

Aim. Determination of the main reasons of the crisis condition of the domestic knitwear industry and the formulation of the main tasks to be solved for the recovery and sustainable development of the domestic knitwear market.

Methods. For researches, the results of which are given in this article, sociological methods were used and their analysis was carried out.

Results. It is established that domestic knitwear products occupy a rather small share in the Ukrainian market, so it is necessary to expand the range of products, creating a competition for imported products of dubious quality. For this purpose, it is necessary to purchase European modern equipment, that would enable to increase the production capacities and increase the quality of production to European standards. It is necessary to create own raw material base for the knitwear industry through the recovery of domestic linen and hemp processing complex. The main trends in the development of the knitwear market in Ukraine are: a reduction in domestic demand for domestically produced knitted goods, due to low import prices; most of the imported products, which account for $76 \%$ of the total market for knitted goods (China, Belarus, Turkey); the decline of the domestic raw material base - the majority of knitted fabrics are imported into the country; knitwear of domestic manufacturers lose competition with imported ones by the criteria: price-quality, compliance with fashion trends, completeness of the range; the outdated technical base and the lack of financial capabilities of domestic enterprises prevent them from rapidly updating the range of knitted goods; large volumes of goods smuggling and dumping prices of foreign competitors make it impossible to compete successfully with domestic producers; Ukraine has no government policy to protect the interests of domestic manufacturers of knitwear. In accordance with this, the task of finding ways to effectively regulate the knitwear market in Ukraine is updated, taking into account the need to protect and stimulate the development of domestic manufacturers at the organizational level of state policy.

An essential condition for the competitiveness of domestic knitwear goods, both in domestic and foreign markets, is the involvement of young designers, who could design modern, fashionable products, in the production of linen products. It is necessary to create an assortment of goods in such a way that the goods specified by an assortment list have always been available. It is necessary to involve buyers in the formation of not only trade but also production assortment through a survey made by sellers or questionnaires.

Original Contribution. It has been established that there are the following priority directions of the formation of the internal market of knitted goods such as, the protection of the market against counterfeit products; compliance with quality control and price of imported goods through the procedures of certification, identification and introduction of electronic declaration of import; application of anti-dumping measures for protection of the domestic market from the expansion of foreign producers; reducing the amount of shadow turnover.

Practical significance. The analysis of the development trends of the knitwear market in Ukraine has made it possible to determine the necessary criteria for the recovery of domestic knitwear production.

Keywords. Knitwear production, certification, identification, shadow turnover, price, quality.

Стаття рекомендована до публікачії доктором технічних наук, професором Херсонського НТУ Тіхосовою Г.А Дата надходження в редакиію 09.02.2019 p. 